\title{
Arabic, Grammar, and Teaching: An Islamic Historical Perspective
}

\author{
NADIA SELIM 1
}

\begin{abstract}
Motivated by the need to rethink Islamic education and Arabic teaching in Western Islamic schools (Ramadan 2004), this article seeks to present an analytical exploration of Islamic educational thought on the purpose of Arabic grammar and its place in Arabic language teaching. The article will review the rise of Arabic grammar and thought surrounding its instruction to understand whether one of the most prevalent approaches to teaching Muslim children Arabic as a foreign or second language today, the Grammar-Translation Method (GTM), is part of the Islamic educational tradition. The GTM, which is not suited to the promotion of childhood literacy or language acquisition and leaves many children disengaged and with stilted rudimentary literacy, is often conflated with the rich philological tradition of the Islamic civilization. However, was nahw [grammar] meant to be the core component of Muslim childhood learning experiences in the way that it is today, or has the GTM method supplanted Islamic civilizational thought on teaching language? This article seeks to answer this question and will do so by reviewing the purpose of the Arabic language in the Islamic civilization, the rise of Arabic grammar and thought surrounding education and Arabic instruction.
\end{abstract}

Keywords: Arabic language, Islamic education, grammar, nahw, Grammar-Translation Method

The 19th-century European Grammar-Translation Method (GTM) lacks theoretical foundation (Richards \& Rodgers 2001) and ignores the communicative aspects of language learning (Patel \& Jain 2008) in favor of rote memorization, grammatical drills, and translation from the target language into the local language. Initially, used to teach Latin and other dead languages, the method was geared to building a reading ability to enable students to appreciate literary content in other languages. This method leaves many students who have spent years learning about the language frustrated with their inability to use it effectively (Richards \& Rodgers 2001). However, the GTM still constitutes the prevalent approach to teaching children Arabic as a foreign or second language in various contexts (Campbell, Dyson, Karim, \& Basima 1993; Dawood 2009; Mall 2001; Mall \& Nieman 2002; Sirajudeen \& Adebisi 2012). There seem to be several possible explanations for this prevalence. Firstly, the GTM demands little of teachers (Richards \& Rodgers 2001) because of its focus on reading, grammar-drills, and translation. Secondly, this approach provides teachers who are unable to use the language effectively (Ismail 1993; Mall \& Nieman 2002) with a controlled language environment in which they can discuss the text theoretically in their local language (Ismail 1993). Thirdly, the shortage of suitable trained Arabic language teachers perpetuates the

\footnotetext{
${ }^{1}$ Nadia Selim, M.A., Ph.D. candidate, Centre for Islamic Thought and Education, Magill Campus, University of South Australia, Room: C1-40, St Bernards Road, MAGILL SA 5072, Australia, email: nadia.selim@mymail.unisa.edu.au.
} 
use of this method, because untrained teachers inadvertently teach as they were taught (al-Batal 2007). This is particularly true of many Islamic settings and has had a detrimental effect on Arabic language acquisition outcomes (Mall 2001; Mall \& Nieman 2002; Sirajudeen \& Adebisi 2012). Though often used to equip Muslims with the ability to read their scriptures, it often falls short of this (Mall \& Nieman 2002) leaving children with rudimentary literacy and poor language competence. More importantly, the method is not suited to educating children and leads to disengagement and attrition (Dawood 2009; Mall \& Nieman 2002; Sirajudeen \& Adebisi 2012). Surprisingly, this method which primes the scrutiny of grammar rules is often conflated with the philological traditions of the Islamic civilization and thus legitimized and sustained as an approach suited to teaching Arabic at Islamic schools. This necessitates exploration of the Islamic educational tradition to determine whether the focus on grammar that this method entails is part of the Islamic educational tradition and whether the continued commitment to this approach is a valid position. However, before we can determine whether the Islamic civilizational educational tradition legitimizes the use of the GTM, we will need to shed some light on the history of Arabic and grammar and their place in the Islamic civilization.

\section{The Arabic Language Is at the Heart of the Islamic Civilization}

The learning of Arabic by non-Arab Muslim converts was inevitable as this was the language of their religion. In the Quran Allah reveals that "So We have sent down the Quran to give judgment in the Arabic language." [13:37] and that "We have sent the Quran down in the Arabic tongue and given all kinds of warnings in it, so that they may beware or take heed" [20:113] among other references to Arabic in the Quran. These commandments were taken seriously. For instance, it is known that Caliph Umar Ibn al-Khattab who died in 644 encouraged Muslims to learn Arabic (Selim 2017). However, all the early Muslim leaders took every measure to ensure that Muslim converts from non-Arab regions of the Muslim empire were equipped with the Arabic language thereby championing one of earliest grassroots literacy campaigns (Lydon 2010; Muhammad 2012).

It is beyond doubt, that the religious injunctions to learn Arabic played a huge role in the successful uptake of the Arabic language by the new communities. Versteegh (2006) explains that Arabic was held in extremely high regard even by non-Arab scholars such as the Persian born Arabic grammarian Sibawayhi (760-796). The esteem awarded to the Arabic language among Muslims at the time did not necessarily draw on the linguistic merit of Arabic, but on the fact that it was the language in which God chose to communicate his final message to humanity. One of the greatest pieces of evidence of this is provided by Suleiman (1989), who notes that linguists in the Islamic civilization, who developed or advanced almost all linguistic sciences, did not care to engage in contrastive analysis of Arabic and any other languages. In fact, it is narrated that Ibn Jinni (9421002) asked 'Ali al-Farisi (901-987) about Arabic and Persian, and the Persian born scholar replied that Arabic "was far superior to Persian both aesthetically and rationally" (Versteegh 2006: 5).

Religious advocacy for the language persisted through the centuries. Muhammad (2012) notes that al-Tha'alibi (961-1038) said, "the one who loves Allah loves his Prophet (PBUH), and the one who loves the Arab Prophet loves the Arabs, and the one who loves the Arabs loves the Arabic language in which the best of books was revealed to all mankind, and the one who loves the Arabic language cares for it and perseveres in its study...". In fact, Ath-Tha'alibi elaborated that Arabic was a means to two ends; acquisition of religious knowledge and elevating one's station in this life and the next (Muhammad, 2012).

Ibn Taymiyyah (1263-1328) took advocacy to another level when he considered the learning of Arabic fard [a religious duty] because it is the means by which the Quran and the 
Sunnah can be understood (Muhammad 2012). He believed that the development of a linguistic habit had an influence on cognition, mannerisms and religiosity. He accordingly considered that learning Arabic constituted emulation of the righteous companions (al-Aql 1998). This is a noteworthy attempt at articulating the deep connections between language, culture, identity, and worldview. More importantly, his view emphasizes that the learning of Arabic was a serious matter for Muslims because it influenced their perception.

However, as alluded to by al-Tha'alibi, there were pragmatic motivations for learning Arabic as well. For instance, this led the non-converted Christian and Jewish communities to learn the Arabic language (Muhammad 2012). Ibn Shabramah (died 761/2) addressed the social mobility facilitated by the learning of Arabic, by highlighting that the ruling elite were known patrons of poets and writers and that high-ranking jobs were awarded to Arabic speakers (Muhammad 2012).

These religious and pragmatic motivations clearly had literacy and communication at their core and were effective in promoting language uptake. In fact, by the time that the Islamic empire had begun to institutionalize learning the "process of Arabicization had already progressed to such an extent that it had become unnecessary to provide any program for second language acquisition" (Versteegh 2006: 4). Essentially, at this stage, most children grew up speaking an Arabic vernacular (Versteegh 2006). Sadly, there is no written record of the exact methods used to achieve this (Muhammad 2012), but the empire's approach neither deemed it acceptable to confine the purpose of learning Arabic to rudimentary literacy, nor confined the role of Arabic to the space of mechanical religious practice. Rather Arabic was fully embraced as a language of religion, culture, and communication at all societal levels. Arabic was a means of binding the Ummah under the banner of one nation and one identity; the Muslim identity. It is, therefore, very safe to conclude that the early Muslims were not in any way ambivalent about Arabic (Selim 2017) because clearly, Arabic to the Islamic civilization was a language of dunyah (world) and akhirah (hereafter). Therefore, it is a curious matter that the descendants of this civilization prime a methodology that was conceived to teach dead languages and produce if anything a stilted ability in the Arabic language.

\section{Arabic Grammar Was Born Out of Love for Islam}

Muslims were farsighted, motivated by a need for the preservation of the Quran they endeavored to become a literary nation, start documenting the Islamic tradition and protect the Arabic language. Drawing on these motives Abu al-Aswad al-Duali (603-689) developed nahw [grammar] (Ibn Khaldun 1377; Muhammad 2012). Ibn al-Anbari (1119-1181) explains that Islam's fourth Caliph 'Ali Ibn Abi Talib (RA) coined the term nahw (Al-Saamerai 1985) and commissioned the services of al-Duali. Versteegh (2013: 3) details Ibn al-'Anbari's full account and explanation of the rise of nahw:

The reason why 'Ali -may God have mercy on him -founded this science is given by 'Abu al-Aswad in the following story: I came to the Commander of the Believers 'Ali ibn Abi Tilib-may God have mercy on him! -and saw in his hand a manuscript. I said to him: "What is this, Commander of the Believers?" He said: "I was reflecting on the language of the Arabs and noted that it had been corrupted by our mixing with these red persons -i.e., foreigners -and I wanted to make something for them on which they could fall back and on which they could rely". Then he handed me the manuscript, and I saw that it said: "Language is noun and verb and particle. The noun is what informs about a named object; the verb is that with which the 
information is given; and the particle is what comes for a meaning". He said to me:

"Follow this direction (unhu hadha n-nahw) and add to it what you find!"

At the center of this account, we find that there are two primary concerns. Firstly, that there was a strong need to codify the grammatical rules of Arabic to protect the language of the Quran from corruption through language contact. Secondly, that the non-native speakers needed something to rely on to gain a correct grasp of the language with ease.

In connection with the first concern, there was a strong "desire to protect this language from the corrosive dangers of lahn [corruption] through the infiltration into its very fabric of nonnative linguistic habits or behaviour" (Suleiman 1989: 178). Muslim expansion into non-Arabic speaking regions meant that Arabic encountered "other" languages and thus protecting its purity was essential (Ibn Khaldun 1377), especially because of its connection with the Quran which had to be preserved as revealed. This concern reached panic level, fairly early in the history of the Muslim empire. Al-Shatibi (1320-1388) reports that by the time of the second Caliph, Umar Ibn al-Khattab, incorrect recitation of words that changed the meaning of verses had become a manifest problem and resulted in a decree being issued by Umar Ibn al-Khattab that no one could instruct the recitation of the Quran unless they were well versed in the Arabic language (al-Samerai 1985; alSalman 2000). Relating to the second concern, and in reference to nahw, Ibn Al-Sarraj's (died 929) explains; "that the speaker by learning it moves towards the Arabic language" (Versteegh 2006: 3). From this, it becomes very clear that Muslims felt that the development of grammar was needed to assist learners in attaining a language ideal. Grammar was to constitute a roadmap that would bring people closer to the attainment language competence.

\section{Why Do We Use the Grammar-Translation Method to Teach Muslim Children Arabic?}

Clearly, Muslims felt that grammar was needed to assist in the preservation of the language and religion. Grammar was also meant to bring people closer to the attainment of competence in a language that was an integral part of their religious and daily lives. However, grammar was neither intended to hinder acquisition nor become the most prominent part of the Arabic learning experience, which calls the contemporary prevalence of the Grammar-Translation method into question. The literature abounds with examples to support this conclusion, and three such examples will be reviewed to support this conclusion. These examples are the Taysir Movement, the Curriculum of Ibn Sahnun (817-870) and the Arguments of Ibn Khaldun (1332-1406).

\section{The Taysir Movement: A Precursor to Arabic for Dummies}

Muslim grammarians such as Ibn Jinni (932-1002), in an early allusion to native speaker intuition, explained that nahw developed because native-speakers, had a grasp of the language and heightened sense of grammaticality but did not always know how to articulate this in technical terms (Suleiman 1989). As the Arab traditions were mostly oral, the extrapolation of Arabic grammar was done inductively through the analysis of Arabic speech to clarify its gharad i.e. purpose (Suleiman 1989). Despite its oral origins, Arabic grammar was a developed science with a phenomenal depth and breadth by the 10th century as was true of other linguistic endeavors.

Unfortunately, the efforts that were expended in expanding the science of nahw, inadvertently rendered it too specialized and complex for students (Ibn Khaldun 1377). This led to students becoming disengaged from its study (Zahran 1996). Therefore, many 10th century grammarians started writing simplified books for students (Versteegh 2006) to try and counter this 
concern. Ibn Jinni (942-1002), a leading Basran grammarian (Meisami \& Starkey 1998), explained that Abu 'Ali al-Farisi (901-987) who was his teacher for 40 years (Meisami \& Starkey 1998), wrote the "Concise elements of declension" because it had become evident that taysir [simplification, facilitation or making accessible] was necessary because students were not coping with the specialist science that nahw had evolved into. Zahran (1996) explains that the aim of "The 100 elements" written by al-Jurjani (1009-1078) was to simplify and make easy the science of grammar to the novice learner who needed to unpack the meaning of the Quran. Zahran (1996) elaborates that al-Jurjani was concerned that grammar may put many learners off learning Arabic and even turn them away from the Quran.

This reformation movement which sought to simplify nahw for learners was the equivalent of writing "Arabic for dummies" and makes evident that there was reflection, evaluation, and rethinking of approaches in response to student needs and in relation to objectives of learning. Clearly, when focus on expanding the science of Arabic grammar hindered language acquisition and threatened to turn students away from the Quran, a call to action followed. This call to action involved realigning purpose with pedagogy and distinguished between grammar as a science (of interest to linguists, grammarians, and shariah scholars) and the basics of grammar as a topic to be taught to novices or students. In fact, Ibn Khaldun (1377: 369) informs us:

Evidence-based argumentation increased, and the approaches to teaching it diversified, as did the disagreements surrounding the syntactical analysis of many of the verses of the Quran because of divergent views on rules, all of which became cumbersome for learners. Then came the later generation with their approach of simplification whilst accommodating all that had been transmitted, as did Ibn Malik in the book Tashil [facilitation] and his like, or their focus on the basics for learners, as did al-Zamakhshary in his book al-Mufassal [ the detailed] and Ibn Al-Hajib in alMuqaddimah [the preface] to that. Perhaps they even composed it in the form of poetry like Ibn Malik did in the two poems, the greater and the smaller, and Ibn Mu'ti in his one thousand verse poem. In totality, the works in this art are too many to be enumerated or fully accounted for and the teaching methods are varied, and the method of the predecessors is different to that of followers.

It is, therefore, impossible to assume the presence of a single overarching approach invested in the primacy of grammar above all other aspects of learning, especially if this approach was ineffective or adversely affecting students' relationship with the language of the Quran.

\section{The Curriculum of Ibn Sahnun}

Ibn Sahnun (817-870) is credited with having laid down the foundations of an Arabic language curriculum (Abdellah \& Haridy 2017; Günther 2005, 2006) in his book كتاب آداب المعلمين or The Book of Teachers' Ethics (Al-Matwi 1972). This book constitutes the first teachers' manual and "provides us with an idea of the beginnings of educational theory and curriculum development in Islam while at the same time showing that certain problems relating to the ninth century continue to concern us today" (Günther 2006: 370). Al-Matwi (1972) explains that this curriculum was targeted at 9thcentury elementary schools or kuttab and that it included compulsory as well as elective topics. As concerns Arabic, the core learning included points of articulation, literacy for precise recitation of the Quran and study of its correct grammatical inflections, as well as its orthographic representation (al-Matwi 1972) which we might best describe as Arabic-mediated religious study.

https://doi.org/10.24035/ijit.13.2018.008 
The elective topics included, calligraphy, proverbs, poetry, legends, writing letters, public speaking or elocution and comprehensive grammar (al-Matwi 1972; Günther 2005, 2006) which constitute topics of Arabic language learning and literacy development.

Looking at this curriculum leads one to draw several conclusions. Firstly, Ibn Sahnun clearly differentiated between írab (correct grammatical inflection) which could be understood as oration in accordance with Arabic grammatical norms, and jami' al-nahw or comprehensive grammar. The former was an essential grammar that helped in differentiating verbs, nouns, and objects and knowing to inflect them correctly. This level of knowledge had an impact on speaking, reading and reciting the Quran and was thus considered a core component. The latter was a specialist science that demanded a higher level of knowledge and understanding of abstract morpho-syntactical concepts. This comprehensive grammar was relegated an elective because students may not be inclined towards its study and need not to be overwhelmed by it. Secondly, there was greater emphasis placed on extensive and varied reading for literacy as is suggested by the inclusion of poetry, legends, and proverbs as the best means of acquiring literacy is more reading (Krashen 2009). Thirdly, the curriculum included topics that encouraged productive skills such as writing letters and public speaking. This is quite a different approach to the status quo of many classrooms today wherein autonomous production is not encouraged, as the GTM focused lessons are geared to drills, word memorization and translation.

In summary, we find that nahw was one elective among five other electives which is a clear indication that it was never meant to dominate the students' learning experience and Arabic study or necessarily be a part of it. Students were only expected to know the basic level of grammar that any child would be taught in an English class today. Moreover, students were given opportunities to practice reading, writing and speaking. This was clearly a precursor to Ibn Khaldun's argument that learning grammar rules alone did not develop language ability. It is also extremely indicative that lessons laden with abstracted grammatical drills, translation, and memorization of word lists are not an indispensable part of the Islamic Civilization's Arabic teaching tradition.

\section{The Arguments of Ibn Khaldun}

When one seeks to understand the language acquisition thought of the Islamic civilization, the master sociologist, historian, ethnographer, and language theorist Ibn Khaldun (1332-1406) is the pinnacle. His book al-Muqaddimah, written in 1377, presented clear views on language, language acquisition and language teaching (Abdellah \& Haridy 2017; Abdussalam 1995; Ben-Ari 2009; Deymi-Gheriani 2008; John 1989; Osman 2003; Soraty 1985). Ibn Khaldun was light years ahead of his time, in fact, Abdellah \& Haridy (2017) identified that Ibn Khaldun's work is still relevant to contemporary discussions about the whole language approach, scaffolding in the Vygotskyan sense (1896-1934), content-based instruction, concern for student completions and even the debate on dispensing with the superiority of native-speaking teacher narrative. Relating to the overemphasis of grammar in contemporary classrooms, Ibn Khaldun's theory of acquisition, evaluation of Arabic teaching approaches and his prolific argumentation against teaching about language are of great interest.

According to Ibn Khaldun, an acquired language is "a firmly rooted habit and quality expression that a speaker (or listener) attains through constant practical use of excellent materials, expert linguistic knowledge, and through a healthy disposition" (Abdussalam 1995: 186). Therefore, knowledge of language rules, while complementary, does not constitute competence in the language (Abdussalam 1995). In terms of developing and assessing language competence, it is interesting that Ibn Khaldun, like Merill Swain (1985) places a great value on comprehensible 
output. Abdussalam (1995: 187) notes that according to Ibn Khaldun, "one indicator of language competence is the ability to give a speech act its proper measure of conformity with the requirements of the context of situation". This stands in sharp contrast with the GTM approach which does not provide opportunities for autonomous language production and thus development of productive skills.

Like Noam Chomsky, Ibn Khaldun believed that the best time to acquire native proficiency in a language is in childhood (Abdussalam 1995), which may have motivated his examination of Arabic teaching and curriculum in Morocco (Maghrib), Spain (Andalusia), Africa (Ifriqiyyah) and the East (the rest of the Muslim world) (Osman 2003). For instance, he notes that handwriting quality was poor in the East, and notes that in Africa the approach to teaching shared some similarities with the Spanish approach due to some collaboration with the Andalusian sheikhs (Ibn Khaldun 1377).

Ibn Khaldun awarded the teaching approaches in Morocco and Spain significant attention. He highlights that in Morocco, children only learned the Quran and its orthography until they either mastered it or dropped out (Dajani 2015). In this regard, Ibn Khaldun (1377) cautioned that this abandonment tended to be of all education, suggesting that the experience was quite traumatic. He deemed the Spanish approach more successful. Although Spanish children also learned the Quran (Dajani 2015; Ibn Khaldun 1377; Osman 2003) they were not put under the same pressure as Moroccan children, because the Quran was not as emphasized (Osman 2003) and learning included Arabic poetry, writing, and grammar (Ibn Khaldun 1377).

Ibn Khaldun drew two important conclusions from his research in this space. The first was with regards to the overemphasis on the Quran as a source of language learning. Ibn Khaldun (1377) notes that because the Quran is the inimitable word of Allah, trying to acquire a language ability through its study is an otiose endeavor. He then explains that because of the unitary Moroccan focus on the Quran, Moroccans did not develop a good command of the Arabic language. In his view, the Spanish grasp of the language was far superior because of their inclusion of other readings. He also notes that although their religious knowledge was not advanced it was sufficiently augmented by their knowledge of Arabic, which this endowed those who wished to further their religious study with the tools they needed to do. Ibn Khaldun also notes that Judge Ibn al-'Araby favored the adoption of the Spanish approach of prioritizing Arabic and poetry as he was bemoaning the fact that children were reading without comprehension. The second was with regards to the overemphasis on nahw. He notes that contrary to what grammarians think, teaching children should not be done through an early introduction to grammar but through direct contact with the language and speech (Osman 2003). Ibn Khaldun argued for teaching language, having grasped unequivocally the difference between acquisition of an Arabic language habit and knowledge of Arabic grammar rules (Soraty 1985). He argues, that this is knowledge of the theory of a language and not the knowledge of a language and would be like learning about a craft but remaining unable to practice it (Osman 2003) because knowledge of a quality does not constitute having the quality itself (Ben-Ari 2009; Ibn Khaldun 1377). In his view, learning Arabic grammar rules only would be the equivalent of knowing the theory of dressmaking but never having sewn a garment (Soraty 1985). In other words, according to Ibn Khaldun (1377), possessing a malakah [i.e. competence/ability] was different from knowledge of i'rab [knowledge of rules]. To exemplify Ibn Khaldun goes a step further and notes that many philologists and grammarians "make many mistakes and commit many solecisms when they are asked to write even a short note. They cannot put the words together and express what they want to say in a way that corresponds to the ways of the Arabic language" (Ben-Ari 2009: 228). In contrast, Ibn Khaldun notes that many people who are highly developed in their linguistic habit know nothing of philology (Soraty 1985) and takes this 
debate further by explaining that it logically follows that philology could be completely dispensed with as concerns developing a language ability.

That is not to say that Ibn Khaldun did not see value in nahw, he did and stated that it was incumbent on scholars of shariah to study it and even prioritize it. However, here it is clear, that like Ibn Sahnun, he distinguished between essential and specialized and comprehensive grammar knowledge. More importantly, he wanted the teaching of Arabic to incorporate more reading and direct contact with the language and its speech. Based on this Osman (2003) argues that Ibn Khaldun is one of the earliest advocates for communicative language teaching (CLT), which gained momentum in the last fifty years (Berns 1990; Lightbown \& Spada 1990; Savignon 1987; Spada 2007; Swain 1985; Yalden 1983). However, the work of Ibn Khaldun must have influenced the likes of Paul Édouard Passy (1859-1940) who advocated for replacing the GTM with the direct method thus launching a reformation of language teaching in Europe.

Nahw had an important role to play in both the preservation of the Arabic language and in presenting learners with a roadmap with which to navigate their acquisition of the language. However, grammar only constituted a component of a broader curriculum as evidenced by the curriculum of Ibn Sahnun wherein comprehensive grammar was an elective and seen as different to essential grammar. More importantly, Ibn Khaldun argued that grammar can be dispensed with when the goal is to develop language ability, as this ability develops through direct contact with the language.

It is hard to do justice to the Islamic educational and scholarship tradition by merely calling it progressive. A stronger word is needed to describe the level of insight, ingenuity, and diligence that motivated these scholars to be at the cutting edge of their fields which rendered their work relevant to discussions on language teaching and education six to eleven centuries later. However, their heightened awareness of the role they play in shaping the futures of children and their relationship with their scriptures was truly remarkable. This is demonstrated by the taysir movement championed by 10 th-century grammarians who realized that study of complex grammar had turned students away from learning and threatened their relationship with din. It is very hard to imagine that such scholars and educators would maintain an ineffective method upon realizing its flawed nature. However, given that these scholars were in support of focusing less on grammar and more on reading and the development of productive skills, it is impossible to reconcile their thought with the GTM. Furthermore, based on what is reported by Ibn Khaldun (1377) about the variety of teaching approaches present in the Islamic civilization it becomes clear that maintaining or upholding the GTM as part of the Islamic educational tradition is an invalid position.

\section{References}

Abdellah, A. \& Haridy, A. 2017. Medieval Muslim thinkers on foreign language pedagogy: The case of Ibn Khaldun. Lingua. 193: 62-71.

Abdussalam, A. S. 1995. The Psycholinguistic Theories in the Muqaddimah of Ibn Khaldūn. Intellectual Discourse. 3(2): 181-196.

Al-Anbari, K. A. M. 1985. Nuzhat al-alibba fi tabaqat al-'udaba: "The excursion of the sensible in the strata of authors by Al-Anbaari (died 1181 CE)". In, I. Al-Saamerai (Ed.). Nuzhat al-Alibba fi Tabaqat al-'Udaba. $3^{\text {rd }}$ ed. Al-Zarqa: Maktabat Al-Manar.

Al-Batal, M. 2007. Arabic and National Language Educational Policy. The Modern Language Journal. 91(2): 268-271. 
Al-Jurjani, A. \& Al-Azhari, K. 1988. The 100 elements of grammar underpinning the science of Arabic. In, E. Zahran (Ed.). Al-'Awamil al-mi'ah al-Nahwìyah fi usul 'Ilm al-'Arabiyyah. (Second ed.). Cairo: Dar El-Maaref.

Al-Matwi, M. A. 1972. Kitab Adab al-Mu'allimin (The Book of Teachers' Ethics) by Muhammad Ibn Sahnun. Tunisia: Dar al-Kutub al-Sharqiyyah.

Al-Shatibi, A. 2000. Al-I'tisam tasnif al-Alama al-Muhaqiq Abi Ishaq Ibrahim Ibn Musah Ibn Muhammad al-Lukhaymi al-Shatibi: "Holding fast: By Abu Ishaq al-Shatibi. Vol. 1. Manama: Maktabat Al-Tawheed.

Ben-Ari, S. 2009. Language, civilisation and globalisation in the 14th century: Historical periodicity and the evolution of language at Ibn Khaldun. Acta Orientalia Academiae Scientiarum Hungaricae. 62(2): 219-230. doi:10.2307/23658977.

Campbell, S., Dyson, B., Karim, S. \& Rabie, B. 1993. Unlocking Australia's Language Potential: Profiles of 9 Key Languages in Australia. Volume 1. Canberra: National Languages and Literacy Institute of Australia.

Dajani, B. A. S. 2015. The Ideal Education in Ibn Khaldun's Muqaddimah. Procedia-Social and Behavioral Sciences. 192: 308-312.

Dawood, S. 2009. Teaching of the Arabic language in South African schools: nature of language and methodology. (Dissertation, Master of Arts), University of South Africa, Pretoria, South Africa.

Fatehi-nezhad, E. \& Rahimi, S. 2008. Abu `Ali al-Farisi. In, W. Madelung \& F. Daftary (Eds.), Encyclopaedia Islamica. Online: BrillOnline Reference Works. http://dx.doi.org/10.1163/1875-9831_isla_COM_0039. Retreieved on: 01/08/2017.

Günther, S. 2005. Advice for teachers: The 9th century Muslim scholars Ibn Sannun and al-Jahiz on pedagogy and didactics. In S. Günther (Ed.). Ideas, Images, and Methods of Portrayal: Insights into Classical Arabic Literature and Islam. Vol. 58: 89-128. Koninklijke Brill NV, Leiden: Brill.

Günther, S. 2006. Be masters in that you teach and continue to learn: Medieval Muslim thinkers on educational theory. Comparative Education Review. 50(3): 367-388.

Ibn Khaldun. A. 2004. Al-Muqaddimah by Ibn Khaldun (1377). A. M. Al-Darwish (Ed.). Damascus: Dar Ya'rub.

Ibn Taymiyyah, T. A. 1998. Iqtida al-Sirat al-Mustaqim li-Mukhalafat aShab al-Jahim li Shaykh alIslam Ibn Taymiyyah "Following the straight path to contradict the people of hell" by Ibn Taymiyyah (died 1328)". In, N. A. Al-Aql (Ed.). Iqtida al-Sirat al-Mustaqim li-Mukhalafat aShab al-Jahim li Shaykh al-Islam Ibn Taymiyyah. $2^{\text {nd. }}$ ed. Al-Riyad: Dar Ishbeelyiah.

Ismail, A. R. B. H. 1993. The teaching of Arabic in the Faculty of Islamic Studies in the National University of Malaysia. (Thesis Ph.D). University of Salford, Manchester.

John, J. 1989. Ibn Khaldun's Views on Language Learning: Their Relevance to Language Learning Today. Islamic Quarterly. 33(3): 153-164.

Krashen, S. 2009. Anything but Reading. Knowledge Quest. 37(5): 19-25.

Lydon, G. 2010. A thirst for knowledge: Arabic literacy, writing paper and Saharan bibliophiles in the Southwestern Sahara. In, G. Krätli \& G. Lydon (Eds.). The Trans-Saharan Book Trade: Manuscript Culture, Arabic Literacy and Intellectual History in Muslim Africa (pp. 35-72). Leiden: Brill.

Mall, M. 2001. Teaching of Arabic to learners in Muslim private schools in South Africa and Botswana. Disertation. Master of Education. University of South Africa, Pretoria, South Africa.

Mall, M. \& Nieman, M. 2002. Problems experienced with the teaching of Arabic to learners in Muslim private schools in South Africa and Botswana. Per Linguam. 18 (2): 42-54. doi:http://dx.doi.org/10.5785/18-2-129. 
Meisami, J. S. \& Starkey, P. 1998. Encyclopedia of Arabic literature. Vol. 2. London: Routledge.

Muhammad, H. I. 2012. Juhud al-'Ulama al-Qudama fi Ta'lim al-Lughah al-'Arabiyyah li-ghayri-inNatiqin biha (The Efforts of the Ancient Scientists in the Teaching of Arabic to Non-Native Speakers). http://www.alukah.net/literature_language/0/37801/. Retrieved on: $10 / 08 / 2017$.

Osman, G. 2003. The Historian on Language: Ibn Khaldun and the Communicative Learning Approach. Middle East Studies Association Bulletin. 37 (1): 50-57. doi:10.2307/23063086.

Patel, M. F. \& Jain, P. M. 2008. English Language Teaching : (methods, Tools \& Techniques). Jaipur: Sunrise Publishers and Distributors.

Richards, J. C. \& Rodgers, T. S. 2001. Approaches and Methods in Language Teaching. (2nd ed.). Cambridge: Cambridge University Press.

Savignon, S. J. 2002. Communicative Language Teaching: Linguistic Theory and Classroom Practice. In S. J. Savignon (Ed.). Interpreting Communicative Language Teaching: Contexts and Concerns in Teacher Education (pp. 1-28). New Haven: Yale University Press.

Selim, N. 2017. Muslim societies' ambivalence to Arabic: reasons, manifestations and consequences. International Journal of Islamic Thought. 11(June): 30-42. doi:10.24035/ijit.11.2017.004

Sirajudeen, A., \& Adebisi, A. 2012. Teaching Arabic as a Second Language in Nigeria. Procedia-Social and Behavioral Sciences. 66: 126-135. doi:10.1016/j.sbspro.2012.11.254.

Soraty, Y. I. 1985. Ibn Khaldun's Views on Man, Society and Education. Ph.D. Thesis. University of Pittsburgh Pittsburgh, PA, USA.

Suleiman, M. 1989. On the underlying foundations of Arabic grammar: a preliminary investigation. British Journal of Middle Eastern Studies. 16 (2): 176-185.

Versteegh, K. 1997. Landmarks in Linguistic Thought: The Arabic Linguistic Tradition. Vol. 3. London: Routledge.

Versteegh, K. 2006. History of Arabic language teaching. In, K. M. Wahba, Z. A. Taha, \& L. England (Eds.). Handbook for Arabic Language Teaching Professionals in the 21 st Century. Mahwah: Routledge. 